\title{
Effect of Thermal Treatment on Synephrine, Ascorbic Acid and Sugar Content of Citrus aurantium (Bitter Orange) Juice
}

\author{
Evren Caglar Eroglu*, Zeynettin Baysal, Mustafa Unlu, Ubeyit Seday, Zafer Karasahin
}

Alata Horticultural Research Institute, Department of Postharvest Physiology, Mersin, TURKEY.

\begin{abstract}
Objective / Purpose: The aim of this study was to understand the change of synephrine, ascorbic acid and sugar contents after thermal treatment of peeled and grated Citrus aurantium (Bitter Orange) Juice. Material and Methods: Citrus aurantium was extracted either by peeling or grating methods. Clarification of juice was achieved by a pectic enzyme. After filtration, juices were thermally treated using rotary evaporator until $67^{\circ}$ Brix. Synephrine, sugar and ascorbic acid analysis were performed with a HPLC system. Results: All compounds' amounts, except synephrine, changed significantly after thermal treatment. The results, given as dry matter based, were as below. Synephrine contents of fruit juice and concentrated juice of grated bitter oranges were $14.15 \mathrm{~g} / \mathrm{L}$ and $12.88 \mathrm{~g} / \mathrm{L}$, respectively. Ascorbic acid contents of fruit juice and concentrated juices of grated sample were 6.33 and $5.85 \mathrm{~g} / \mathrm{L}$, respectively. Synephrine content of peeled fruit juice and concentrated samples were 12.84 and $10.64 \mathrm{~g} / \mathrm{L}$, respectively. Ascorbic acid content of peeled fruit juice and concentrated samples were 5.28 and $4.31 \mathrm{~g} / \mathrm{L}$, respectively. Conclusion: Thermal treatment has no significant effect on synephrine content of fruit juices. Ascorbic acid content decreased significantly after thermal treatment. Moreover, glucose and fructose content of samples increased and sucrose content diminished significantly.
\end{abstract}

Key words: Bitter (Sour) Orange, Citrus aurantium, Ascorbic Acid, Synephrine, Thermal Treatment.

\section{INTRODUCTION}

Citrus aurantium L. var. amara is also called sour orange, Seville orange and bitter orange. It is a plant belonging to the Rutaceae family. ${ }^{1}$ The origin of the plant is East Africa and Tropical Asia. It is used hundreds of years to remedy headaches, indigestion, to aid weight loss and for treatment of cancer. ${ }^{2-4}$ It is also used pharmacologically as a vasoconstrictor. $^{5}$ Primary constituents of the plant are adrenergic amines, which mimic like endogenous agonists of nervous system and stimulate thermogenesis and conduce to lipolysis in the body. ${ }^{6} P$-synephrine is the most important alkaloid of the bitter orange. After banning of ephedrine in US market, because of increasing blood pressure and heart rate and some cardiovascular abnormalities, synephrine has become best alternative. Some studies, being carried out to determine the adverse effects of synephrine, show that synephrine doesn't lead any side effect in the limits of daily dosages. These limits were defined by several studies. According to Hansen et al. ${ }^{7}$ doses of up to $100 \mathrm{mg}$ of synephrine per $\mathrm{kg}$ body weight did not show any toxicity on embryo development. Kaats et al. ${ }^{8}$ reported that $98 \mathrm{mg} /$ day usage of synephrine appeared to be without adverse effects. Ascorbic acid (Vitamin C) is a very well-known and easily accessible antioxidant. ${ }^{9-12}$ Citrus fruits are good sources of ascorbic acid. ${ }^{13,14}$ Sugar are the major
DOI: 10.5530/ijper.51.3s.58 Correspondence: Evren Caglar Eroglu, Alata Horticultural Research Institute, Department of Postharvest Physiology, Mersin, TURKEY

Phone no: 0090-5055482936 Email Id : evcager@gmail. com 
component of all citrus species. Bitter orange has glucose, fructose and sucrose, which are compose almost $80 \%$ of all carbohydrate constituents. ${ }^{15}$ Citrus fruits can be consumed both as raw and after processing. Thermal treatment can usually be applied for longer shelf lives of fresh fruits. Most studies showed that after heat processing of fresh fruit, some bioactive ingredients are degraded. However, there are some exception that heat treatment can increase bioactivity positively. Improvement of lycopene and $\beta$-carotene bioactivity after cooking process of tomato and carrots are good examples for this case. ${ }^{16}$

The aim of this study was to understand the change of synephrine, ascorbic acid and sugar content after thermal treatment of peeled and grated Seville (bitter) orange juice.

\section{MATERIAL AND METHODS}

Bitter oranges were collected from garden of Alata Horticultural Research Institute, Mersin, Turkey. The time of harvesting was decided according to maturity index ratio of fruit ( ${ }^{\circ}$ Brix/acidity). Samples were harvested on January and March. All chemicals were of analytical grade

\section{Thermal treatment}

Bitter oranges were cleaned in water and divided in two for peeling and grating extraction processes. After extraction and finishing at $1000 \mathrm{rpm}$, juice were pasteurized at $85^{\circ} \mathrm{C}$ for $3 \mathrm{~min}$. Pasteurized fruit juices were clarified with a pectic enzyme, Pectinex Ultra clear, Novozyme (Denmark). Juices were filtrated with rough filter paper under vacuum. Filtrated samples were aliquoted and stored at $-20^{\circ} \mathrm{C}$ until analyzed. Thermal treatment was held using rotary evaporator (Heidolph, Germany) up to $67^{\circ}$ Brix.

\section{Synephrine, ascorbic acid and sugar analysis}

Synephrine, ascorbic acid, sugar analysis were performed using a Shimadzu 20 AD (Japan) HPLC system consisting of a diode array detector (DAD) and refractive index detector (RID). All Samples were diluted to $\sim 5^{\circ}$ Brix with water, centrifuged at $12,000 \mathrm{~g}$ and filtered through $0.45 \mu \mathrm{m}$ nylon syringe filter.

Synephrine were determined according to modified method defined by Dragull et al. ${ }^{17} 10 \mu \mathrm{L}$ of samples were separated by Inertsil ODS3 (4,6x150 mm 5 $\mu \mathrm{m})$ column. Isocratic flow of acetonitrile $/ \mathrm{H}_{2} \mathrm{O}[90: 10(\mathrm{v} / \mathrm{v})$ with $10 \mathrm{mM}$ ammonium acetate] was finished after $15 \mathrm{~min}$ of elution. Flow rate was constantly $1 \mathrm{~mL} / \mathrm{min}$. Ascorbic acid content were found according to modified method of Ozkan et al. ${ }^{18} 20 \mu \mathrm{L}$ of samples were injected to
HPLC system with diode array detector. Detection was at $254 \mathrm{~nm}$. Separation was achieved at Inertsil ODS3 (4.6x250 mm 5 $\mu \mathrm{m})$ column. $0.2 \mathrm{M}$ potassium dehydrogenase phosphate $\left(\mathrm{KH}_{2} \mathrm{PO}_{4}\right)$ solution (adjusted to pH 2.4 with $\mathrm{H}_{3} \mathrm{PO}_{4}$ ) was eluted isocratic ally as mobile phase at a flow rate of $0.5 \mathrm{~mL} / \mathrm{min}$. Sugar contents of samples were analyzed according to modified method of Mendes et al..$^{19}$ Sugars were separated by Shim-pack $\mathrm{NH}_{2}$ column $(4.6 \times 250 \mathrm{~mm} 5 \mu \mathrm{m})$ at $25^{\circ} \mathrm{C}$ and detected by refractive index detector at $225 \mathrm{~nm}$. Mobile phase of ACN: $\mathrm{H}_{2} \mathrm{O}(80 / 20)$ was eluted isocratically at a rate of $1.3 \mathrm{~mL} / \mathrm{min} .20 \mu \mathrm{L}$ of samples were injected.

\section{Statistical analysis}

Statistical analysis were performed by IBM-SPSS 20. Means were analyzed by one way ANOVA followed by post-hoc Tukey's test. Statistical significance was defined as a two-sided $\alpha<0.05$.

\section{RESULTS \& DISCUSSION}

Synephrine, ascorbic acid, reducing sugars and sucrose contents of thermally processed samples were compared with control sample (fruit juice) on wet basis and dry matter basis. Results are shown in Table 1 .

Wet basis results clearly indicate that all compound's amounts increased significantly $(p<0.05)$. Synephrine contents of grated and peeled fruit juice were found as $1.16 \mathrm{~g} / \mathrm{L}$ and $1.10 \mathrm{~g} / \mathrm{L}$ respectively. The results were compatible with some studies. According to Sun et al..$^{20}$ synephrine content of bitter orange was $2.25 \mathrm{~g} / \mathrm{kg}$. Pellati et al. ${ }^{21}$ reported that synephrine percentages of fruit juice and dry extract of bitter orange were $0.1-0.35 \%$ and $3.5-3.08 \%$, respectively.

Ascorbic acid contents of grated and peeled fruit juices were 0.57 and $0.48 \mathrm{~g} / \mathrm{L}$, respectively. Ascorbic acid content of blood orange was between 0.318 and $0.416 \mathrm{~g} / \mathrm{L} .{ }^{13}$ According to Gazdik et al. ${ }^{22}$ ascorbic acid amount of bitter orange was between 0.30 to $0.56 \mathrm{~g} / \mathrm{kg}$ fresh weight. In another study, ascorbic acid contents of peeled lemon juice and peel of lemon fruit were 0.48 and $0.60 \mathrm{~g} / \mathrm{L}$, respectively. However that of grapefruits were 0.35 and $0.44 \mathrm{~g} / \mathrm{L} .{ }^{23}$ Ascorbic acid content of conventionally pasteurized grape juice decreased from $0.36 \mathrm{~g} / \mathrm{kg}$ to $0.34 \mathrm{~g} / \mathrm{kg}^{24}$ This results are compatible with present study.

In order to understand the effect of thermal treatment on control sample, the results were converted to dry matter basis. According to Table 1, except for synephrine, all compounds' contents changed significantly after thermal treatment $(\mathrm{p}<0.05)$. 


\begin{tabular}{|c|c|c|c|c|c|c|c|}
\hline & \multirow[b]{2}{*}{ Compound } & \multicolumn{3}{|c|}{ Wet Basis } & \multicolumn{3}{|c|}{ Dry Basis } \\
\hline & & $\begin{array}{c}\text { Fruit Juice } \\
\text { (Control) }\end{array}$ & $\begin{array}{l}\text { Thermal } \\
\text { Treated }\end{array}$ & $p$ Value & $\begin{array}{l}\text { Fruit Juice } \\
\text { (Control) }\end{array}$ & $\begin{array}{l}\text { Thermal } \\
\text { Treated }\end{array}$ & $p$ Value \\
\hline \multirow{5}{*}{ } & Synephrine $^{1}$ & $1.16 \pm 0.09$ & $7.21 \pm 0.20$ & 0.001 & $14.15 \pm 0.84$ & $12.88 \pm 0.44$ & 0.200 \\
\hline & Ascorbic Acid ${ }^{1}$ & $0.57 \pm 0.05$ & $3.29 \pm 0.35$ & $<0.001$ & $6.33 \pm 0.07$ & $5.85 \pm 0.53$ & 0.013 \\
\hline & Fructose $^{2}$ & $1.86 \pm 0.04$ & $14.87 \pm 0.09$ & $<0.001$ & $23.76 \pm 0.44$ & $26.58 \pm 0.36$ & 0.020 \\
\hline & Glucose $^{2}$ & $1.81 \pm 0.17$ & $16.33 \pm 0.72$ & 0.001 & $22.82 \pm 0.41$ & $28.61 \pm 0.53$ & 0.007 \\
\hline & Sucrose $^{2}$ & $1.20 \pm 0.07$ & $7.56 \pm 0.06$ & $<0.001$ & $14.87 \pm 0.23$ & $8.78 \pm 0.41$ & 0.003 \\
\hline \multirow{5}{*}{ 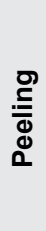 } & Synephrine $^{1}$ & $1.10 \pm 0.11$ & $5.47 \pm 0.25$ & 0.002 & $12.84 \pm 0.55$ & $10.64 \pm 0.48$ & 0.051 \\
\hline & Ascorbic Acid ${ }^{1}$ & $0.48 \pm 0.07$ & $2.32 \pm 0.07$ & 0.002 & $5.28 \pm 0.09$ & $4.31 \pm 0.04$ & 0.006 \\
\hline & Fructose $^{2}$ & $2.19 \pm 0.07$ & $16.17 \pm 0.27$ & $<0.001$ & $24.84 \pm 0.24$ & $27.51 \pm 0.42$ & 0.017 \\
\hline & Glucose $^{2}$ & $2.39 \pm 0.06$ & $19.17 \pm 0.89$ & 0.001 & $26.30 \pm 0.21$ & $30.96 \pm 1.18$ & 0.018 \\
\hline & Sucrose ${ }^{2}$ & $1.39 \pm 0.02$ & $6.16 \pm 0.12$ & $<0.001$ & $17.21 \pm 0.28$ & $10.13 \pm 0.25$ & 0.001 \\
\hline
\end{tabular}

${ }^{1}$ :units as $\mathrm{g} / \mathrm{L},{ }^{2}$ : units as $\%$

Synephrine content of grated fruit juice was $14.15 \mathrm{~g} / \mathrm{L}$ and this value decreased to $12.88 \mathrm{~g} / \mathrm{L}$ at the end of thermal treatment. This decreasing were statistically insignificant $(p=0.2)$. There are some similar results that synephrine and other amines were resistant to thermal degradation during concentration processing. ${ }^{25}$ Ascorbic acid content was one of the heat damage indicator of thermal processing. ${ }^{24,26}$ Therefore, decreasing of ascorbic acid content after thermal treatment was an expected result. In present study, ascorbic acid content of control sample $(6.33 \mathrm{~g} / \mathrm{L})$ diminished to $5.85 \mathrm{~g} / \mathrm{L}$ after heat treatment. The results were comparable with previous studies. After $30 \mathrm{~min}$ of heating processing of tomato juice, ascorbic acid content decreased from $0.76 \mu \mathrm{mol} / \mathrm{g}$ to $0.54 \mu \mathrm{mol} / \mathrm{g} .{ }^{27}$ Although fructose and glucose content increased $11 \%$ and $25 \%$ respectively, sucrose content decreased $40 \%$ after thermal treatment. The reason of this decreasing in sucrose was due to hydrolysis of sucrose into glucose and fructose during thermal treatment in order to yield hydroxyl methyl furfural (HMF). ${ }^{28}$ Synephrine content of thermal treated and peeled sample decreased also from 12.84 to $10.64 \mathrm{~g} / \mathrm{L}$. Despite to this decreasing, there were no statistically differences between thermally treated and control sample $(p=0.051)$. Synephrine and ascorbic contents of peeled samples were slightly less than grated ones $(12.85 \mathrm{~g} / \mathrm{L}$ and $5.28 \mathrm{~g} / \mathrm{L}$ respectively). However, fructose, glucose and sucrose content of peeled fruit juice was higher than that of grated samples $(24.84,26.30$ and $17.21 \%$, respectively).

\section{CONCLUSION}

The results show that thermal treatment of bitter orange doesn't have significant effect on synephrine content of fruit juices. However, ascorbic acid content of grated and peeled bitter orange juice significantly diminished. After thermal treatment, while glucose and fructose content of samples increased, sucrose content diminished significantly.

\section{ACKNOWLEDGMENT}

This study was funded by Ministry for Food, Agriculture and Livestock of Turkey, GDAR (Project No: TAGEM/HSGYAD/16/A05/P01/106).

\section{CONFLICT OF INTEREST}

None

\section{ABBREVIATION USED}

DAD: Diode array detector; RID: Refractive index detector; HMF: Hydroxyl methyl furfural.

\section{REFERENCES}

1. Pellati F, Benvenuti S, Melegari M. Enantioselective LC analysis of synephrine in natural products on a protein-based chiral stationary phase. J Pharmaceut Biomed. 2005;37(5):839-49.

2. Haaz S, Fontaine KR, Cutter G, Limdi N, Perumean-Chaney S, Allison DB. Citrus aurantium and synephrine alkaloids in the treatment of overweight and obesity: an update. Obes Rev. 2006;7(1):79-88.

3. Allison DB, Cutter G, Poehlman ET, Moore DR, Barnes S. Exactly which synephrine alkaloids does Citrus aurantium (bitter orange) contain? Int J Obesity. 2005;29(4):443-6. 
4. Penzak SR, Jann MW, Cold JA, Hon YY, Desai HD, Gurley BJ. Seville (sour) orange juice: Synephrine content and cardiovascular effects in normotensive adults. J Clin Pharmacol. 2001;41(10):1059-63.

5. Stohs SJ, Preuss HG, Shara M. The Safety of Citrus aurantium (Bitter Orange) and its Primary Protoalkaloid p-Synephrine. Phytother Res. 2011;25(10):1421-8.

6. Mercolini L, Mandrioli R, Trere T, Bugamelli F, Ferranti A, Raggi MA. Fast CE analysis of adrenergic amines in different parts of Citrus aurantium fruit and dietary supplements. J Sep Sci. 2010;33(16):2520-7.

7. Hansen DK, Juliar BE, White GE, Pellicore LS. Developmental Toxicity of Citrus aurantium in Rats. Birth Defects Res B. 2011;92(3):216-23.

8. Kaats GR, Miller H, Preuss HG, Stohs SJ. A 60 day double-blind, placebocontrolled safety study involving Citrus aurantium (bitter orange) extract. Food Chem Toxicol. 2013;55:358-62.

9. Levine M, Wang YH, Padayatty SJ, Morrow J. A new recommended dietary allowance of vitamin $\mathrm{C}$ for healthy young women. P Natl Acad Sci USA. 2001;98(17):9842-6.

10. Nakayama N, Yamaura K, Shimada M, Ueno K. Extract from peel of Citrus natsudaidai alleviates experimental chronic allergic dermatitis in mice. Pharmacognosy Research. 2011;3(3):155-9.

11. Narang N, Jiraungkoorskul W. Anticancer activity of key lime, Citrus aurantifolia. Pharmacognosy Reviews. 2016;10(20):118-22.

12. Rao KS, Munjuluri PR, Keshar NK. In vitro Antioxidant Activity and Total Phenolic Content of Mimusops elengi Bark. Indian J Pharm Educ Res. 2011;45(4):317-23.

13. Kafkas E, Ercisli S, Kemal K, Baydar K, Yilmaz H. Chemical composition of blood orange varieties from Turkey: A comparative study. Pharmacognosy Magazine. 2009;5(20):329-35.

14. Lobo V, Patil A, Phatak A, Chandra N. Free Radicals, Antioxidants and Functional foods: Impact on human health. Pharmacognosy Reviews. 2010;4(8):118-26.

15. Kelebek H, Selli S, Canbas A, Cabaroglu T. HPLC determination of organic acids, sugars, phenolic compositions and antioxidant capacity of orange juice and orange wine made from a Turkish cv. Kozan. Microchem J. 2009;91(2):187-92.
16. Choi Y, Lee SM, Chun J, Lee HB, Lee J. Influence of heat treatment on the antioxidant activities and polyphenolic compounds of Shiitake (Lentinus edodes) mushroom. Food Chem. 2006;99(2):381-7.

17. Dragull K, Breksa AP, Cain B. Synephrine content of juice from Satsuma mandarins (Citrus unshiu Marcovitch). J Agr Food Chem. 2008;56(19):8874-8.

18. Ozkan M, Kirca A, Cemeroglu B. Effects of hydrogen peroxide on the stability of ascorbic acid during storage in various fruit juices. Food Chem. 2004;88(4):591-7.

19. Mendes E, Proença BE, Ferreira IMPLVO, Ferreira MA. Quality evaluation of Portuguese honey. Carbohyd Polym. 1998;37(3):219-23.

20. Sun YJ, Qiao LP, Shen Y, Jiang P, Chen JC, Ye XQ. Phytochemical Profile and antioxidant activity of physiological drop of citrus fruits. J Food Sci. 2013;78(1):C37-42.

21. Pellati F, Benvenuti S, Melegari M. High-performance liquid chromatography methods for the analysis of adrenergic amines and flavanones in Citrus aurantium L. var. amara. Phytochem Analysis. 2004;15(4):220-5.

22. Gazdik Z, Zitka O, Petrlova J, Adam V, Zehnalek J, Horna A, et al. Determination of Vitamin C (Ascorbic Acid) using high performance liquid chromatography coupled with electrochemical detection. Sensors-Basel. 2008;8(11):7097-112.

23. Gorinstein S, Martín-Belloso O, Park Y-S, Haruenkit R, Lojek A, Ĉiž M, et al. Comparison of some biochemical characteristics of different citrus fruits. Food Chem. 2001;74(3):309-15.

24. Igual M, García-Martínez E, Camacho MM, Martínez-Navarrete N. Effect of thermal treatment and storage on the stability of organic acids and the functional value of grapefruit juice. Food Chem. 2010;118(2):291-9.

25. Vieira SM, Silva TM, Glória MBA. Influence of processing on the levels of amines and proline and on the physico-chemical characteristics of concentrated orange juice. Food Chem. 2010;119(1):7-11.

26. Destani F, Cassano A, Fazio A, Vincken J-P, Gabriele B. Recovery and concentration of phenolic compounds in blood orange juice by membrane operations. J Food Eng. 2013;117(3):263-71.

27. Dewanto $\mathrm{V}, \mathrm{Wu} \mathrm{X}$, Adom KK, Liu RH. Thermal processing enhances the nutritional value of tomatoes by increasing total antioxidant activity. J Agr Food Chem. 2002;50(10):3010-4

28. Garza S, Ibarz A, Pagan J, Giner J. Non-enzymatic browning in peach puree during heating. Food Res Int. 1999;32(5):335-43.

\section{PICTORIAL ABSTRACT}

\begin{tabular}{|c|c|c|c|c|c|c|c|}
\hline \multirow{2}{*}{\multicolumn{2}{|c|}{ Plot Area mpound }} & \multicolumn{3}{|c|}{ Wet Basis } & \multicolumn{3}{|c|}{ Dry Basis } \\
\hline & & $\begin{array}{l}\text { Fruit Juice } \\
\text { (Control) }\end{array}$ & \begin{tabular}{|l} 
Thermal \\
Treated
\end{tabular} & $p$ Value & \begin{tabular}{|l} 
Fruit Juice \\
(Control)
\end{tabular} & $\begin{array}{l}\text { Thermal } \\
\text { Treated }\end{array}$ & $p$ Value \\
\hline \multirow{5}{*}{ 咙 } & Synephrine $^{1}$ & $1.16 \pm 0.09$ & $7.21 \pm 0.20$ & 0.001 & $14.15 \pm 0.84$ & $12.88 \pm 0.44$ & 0.200 \\
\hline & \begin{tabular}{|l|} 
Ascorbic Acid $^{1}$ \\
\end{tabular} & $0.57 \pm 0.05$ & $3.29 \pm 0.35$ & $<0.001$ & $6.33 \pm 0.07$ & $5.85 \pm 0.53$ & 0.013 \\
\hline & Fructose $^{2}$ & $1.86 \pm 0.04$ & $14.87 \pm 0.09$ & $<0.001$ & $23.76 \pm 0.44$ & $26.58 \pm 0.36$ & 0.020 \\
\hline & Glucose $^{2}$ & $1.81 \pm 0.17$ & $16.33 \pm 0.72$ & 0.001 & $22.82 \pm 0.41$ & $28.61 \pm 0.53$ & 0.007 \\
\hline & \begin{tabular}{|l} 
Sucrose $^{2}$ \\
\end{tabular} & $1.20 \pm 0.07$ & $7.56 \pm 0.06$ & $<0.001$ & $14.87 \pm 0.23$ & $8.78 \pm 0.41$ & 0.003 \\
\hline \multirow{5}{*}{ 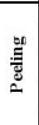 } & Synephrine $^{1}$ & $1.10 \pm 0.11$ & $5.47 \pm 0.25$ & 0.002 & $12.84 \pm 0.55$ & $10.64 \pm 0.48$ & 0.051 \\
\hline & Ascorbic Acid $^{1}$ & $0.48 \pm 0.07$ & $2.32 \pm 0.07$ & 0.002 & $5.28 \pm 0.09$ & $4.31 \pm 0.04$ & 0.006 \\
\hline & Fructose $^{2}$ & $2.19 \pm 0.07$ & $16.17 \pm 0.27$ & $<0.001$ & $24.84 \pm 0.24$ & $27.51 \pm 0.42$ & 0.017 \\
\hline & Glucose $^{2}$ & $2.39 \pm 0.06$ & $19.17 \pm 0.89$ & 0.001 & $26.30 \pm 0.21$ & $30.96 \pm 1.18$ & 0.018 \\
\hline & Sucrose $^{2}$ & $1.39 \pm 0.02$ & $6.16 \pm 0.12$ & $<0.001$ & $17.21 \pm 0.28$ & $10.13 \pm 0.25$ & 0.001 \\
\hline
\end{tabular}

\section{SUMMARY}

- Thermal treatment has no significant effect on synephrine content of bitter orange juices.

- Although, ascorbic acid and sucrose contents decreased, glucose and fructose contents increased significantly after thermal treatment.

\section{About Authors}

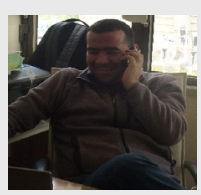

Evren Caglar Eroglu Working as Research Specialist at ALATA Horticultural Research Institute, Ministry of Food, Agriculture and Livestock, Mersin, Turkey. His research subjects are biotechnology, food chemistry; esp. enzyme technology, protein purification and identification; microbiology; postharvest studies and functional food researches. 
Mustafa Unlu Working as Research Specialist at ALATA Horticultural Research Institute, Ministry of Food, Agriculture and Livestock, Mersin, Turkey. He has more than 50 research publications being published in National and International Journals.

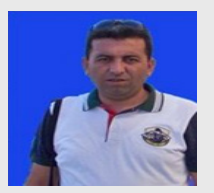

Ubeyit Seday Working as Research Specialist at ALATA Horticultural Research Institute, Ministry of Food, Agriculture and Livestock, Mersin, Turkey. He has more than 13 research publications in International Journals and 10 developed varieties

Cite this article: Eroglu EC, Baysal Z, Unlu M, Seday U, Karasahin Z. Effect of Thermal Treatment on Synephrine, Ascorbic Acid and Sugar Content of Citrus aurantium (Bitter Orange) Juice. Indian J of Pharmaceutical Education and Research. 2017;51(3)Suppl:S412-16. 